\title{
Article \\ Conversion of a Thiol Precursor into Aroma Compound 4-mercapto-4-methyl-2-pentanone Using Microbial Cell Extracts
}

\author{
Hao-Kai Li ${ }^{1,+}{ }^{\dagger}$ Chi-Fon Chang ${ }^{2,+}$, Hsuan-Ju Lin ${ }^{3,+}{ }^{+}$Jung-Lee Lin ${ }^{2}$, Yu-Ting Lee ${ }^{3}$, Yu-Hsuan Wu ${ }^{3}$, Chiao-Yen Liu ${ }^{3}$, \\ Tze-Chia Lin $1, *$, Pang-Hung Hsu $4,5,6, *(1)$ and Hong-Ting Victor Lin $3,6, *$ (1)
}

check for

updates

Citation: Li, H.-K.; Chang, C.-F.; Lin, H.-J.; Lin, J.-L.; Lee, Y.-T.; Wu, Y.-H.; Liu, C.-Y.; Lin, T.-C.; Hsu, P.-H.; Lin, H.-T.V. Conversion of a Thiol Precursor into Aroma Compound 4-mercapto-4-methyl-2-pentanone Using Microbial Cell Extracts. Fermentation 2021, 7, 129. https:// doi.org/10.3390/fermentation7030129

Academic Editors: Flavia Marinelli, Fabrizio Beltrametti and

Francesca Berini

Received: 27 June 2021

Accepted: 16 July 2021

Published: 26 July 2021

Publisher's Note: MDPI stays neutral with regard to jurisdictional claims in published maps and institutional affiliations.

Copyright: (C) 2021 by the authors Licensee MDPI, Basel, Switzerland. This article is an open access article distributed under the terms and conditions of the Creative Commons Attribution (CC BY) license (https:// creativecommons.org/licenses/by/ $4.0 /)$.
1 K. F. Lings Co., Ltd., No. 294, Furong Street, Bade Zone, Taoyuan 334, Taiwan; haokaili43@gmail.com

2 Genomics Research Center, Academia Sinica, No. 128, Sec. 2, Academia Rd., Taipei 115, Taiwan; chifon@gate.sinica.edu.tw (C.-F.C.); harrylin@gate.sinica.edu.tw (J.-L.L.)

3 Department of Food Science, National Taiwan Ocean University, No. 2, Pei-Ning Road, Keelung 202, Taiwan; angel810801@gmail.com (H.-J.L.); f0886446.angel@gmail.com (Y.-T.L.); yuiop0333@gmail.com (Y.-H.W.); daisy18288600@gmail.com (C.-Y.L.)

4 Department of Bioscience and Biotechnology, National Taiwan Ocean University, No. 2, Pei-Ning Road, Keelung 202, Taiwan

5 Institute of Biochemistry and Molecular Biology, National Yang Ming Chiao Tung University, No. 155, Sec. 2, Linong Street, Taipei 112, Taiwan

6 Center of Excellence for the Oceans, National Taiwan Ocean University, No. 2, Pei-Ning Road, Keelung 202, Taiwan

* Correspondence: kflings@ms52.hinet.net (T.-C.L.); phsu@ntou.edu.tw (P.-H.H.); HL358@ntou.edu.tw (H.-T.V.L.); Tel.: +886-3-3638057 (ext. 201) (T.-C.L.); +886-2-24622192 (ext. 5567) (P.-H.H.); +886-2-24622192 (ext. 5121) (H.-T.V.L.); Fax: +886-2-24634203 (H.-T.V.L.)

+ These authors contributed equally to this work.

Abstract: 4-Mercapto-4-methyl-2-pentanone (4MMP), a high-impact aroma compound with the box tree and black currant flavors was first identified in wines and could be released by microbial cysteineS-conjugate $\beta$-lyases from its precursors. In this study, various yeasts and bacteria encoding $\beta$-lyases were selected to examine their $\beta$-lyase activities. A thiol precursor of $4 \mathrm{MMP}$, cysteine-conjugate of $4 \mathrm{MMP}$ (cys-4MMP), was synthesized with a purity of $>95 \%$ in a relatively environmentally friendly approach, and its chemical structure was confirmed by nuclear magnetic resonance spectroscopy. The $\beta$-lyase activities of the crude cell extract from the bacteria and yeast strains for different substrates were examined using a colorimetric method. Shewanella putrefaciens cell extract exhibited the highest $\beta$-lyase activity for all tested substrates. Additionally, the optimum $\mathrm{pH}$ and temperature for their $\beta$-lyase activities were determined. To monitor the conversion efficiency of precursor cys-4MMP to 4MMP, liquid chromatography-mass spectrometry was used. Our data indicate that selected bacteria and yeasts could convert cys-4MMP into 4MMP, and S. putrefaciens exhibited the best conversion yield. This study demonstrated the potential use of microbial cell extracts to produce sulfur-containing aroma compounds such as 4MMP.

Keywords: aroma compounds; 4-mercapto-4-methyl-2-pentanone; $\beta$-lyase; precursors; fermentation; Shewanella putrefaciens

\section{Introduction}

The global food flavor market is approximately valued at 16.4 billion U.S. dollars in 2020 and is estimated to reach 20.7 billion by 2025 [1]. The global market has been pursuing flavorings from natural origins instead of chemical synthesis due to possible negative impacts on the environment, lack of matrix selectivity, and customer perceived value [2,3]. However, the direct extraction of natural flavors from plants and animals also faces challenges such as insufficient sources, increased costs, seasonal factors, and plant diseases (Longo and Sanroman, 2006). As a result, the prices of natural flavorings have been rising. The production of aroma compounds via microbial fermentation and enzymatic 
transformation has been drawing attention recently. Butter-flavored butyric acid was produced from sugar fermentation via intermediate acetyl-CoA by the absolute anaerobic genus Clostridium [4]. Previous reports have indicated that Streptomyces sp. has transformed ferulic into aroma compound vanillin [5,6]. Elderberry juice was added with Lactobacillus casei cell-free extracts and whole cells, individually, and the former generated the highest amount of esters, formed by the esterification of acids and alcohols [7]. Furthermore, microbial enzymes such as lipase, glycosidase, and carbon-sulfur lyase, have been reported to transform non-volatile compounds into volatile compounds for flavor production [8-11].

Volatile sulfur compounds have low odor thresholds and account for approximately $10 \%$ of edible aroma compounds. Although the content of volatile sulfur aroma compounds in foods is relatively low, they play an essential role in the aroma notes of food, such as fruity, meaty, coffee, and vegetable notes [12]. Cysteine-S-conjugate $\beta$-lyase (EC 4.4.1.13) and cystathionine $\beta$-lyase (EC 4.4.1.8) (now included in cysteine-S-conjugate $\beta$-lyase from 2018) are cellular metabolic enzymes involved in sulfur-containing amino acid biosynthesis. They can catalyze $\beta$-elimination reactions with cysteine-S-conjugates and sometimes with aliphatic and aromatic substitutions [13]. Cysteine-S-conjugate $\beta$-lyase mainly exists in the form of tetramers and contains pyridoxal $5^{\prime}$-phosphate (PLP) as a cofactor [13], and it has been reported to be involved in the release of volatile sulfur-containing aroma compounds in fermented foods, such as cheeses and alcoholic beverages. It has been reported that L. helveticus CNRZ 32-expressing cystathionine $\beta$-lyase could increase the volatile sulfurcontaining compounds methanethiol and dimethyl disulfide during cheese ripening [14]. Yeast Saccharomyces cerevisiae was reported to be responsible for the sulfur-containing compound 2-furfurylthiol in Chinese distilled liquor Baijiu [15], and S. cerevisiae-expressing cystathionine $\beta$-lyases Str3 and Cys3 could enhance the release of 2-furfurylthiol from cysteine-S conjugates [16].

Sulfur-containing compounds are also responsible for the organoleptic properties of wine. For example, 4-mercapto-4-methyl-2-pentanone (4MMP) $\left(\mathrm{C}_{6} \mathrm{H}_{12} \mathrm{OS}\right)$ (blackcurrant and catty flavors) has been identified in Sauvignon blanc wine $[17,18]$ and plays a vital role in aromatic complexity and typicity in wine. $4 \mathrm{MMP}$ has been reported to be released from the precursor by cysteine-S-conjugate $\beta$-lyase in the process of yeast alcohol fermentation, but the conversion rate was low $(<5 \%)[19,20]$. Whole cells, cell extracts, and pure enzymes have been investigated for flavor enrichment or production of 4MMP, but most studies focused on lactic acid bacteria and yeast Saccharomyces cerevisiae $[8,11,19]$. This study screened cell extracts from bacteria, such as Bacillus subtilis, E. limosum, Lactobacillus bulgaricus, Lactobacillus casei, and Shewanella putrefaciens, as well as yeasts, such as S. cerevisiae, Kluyveromyces marxianus, Kluyveromyces lactis, Debaryomyces hansenii, and Schizosaccharomyces pombe, for their cysteine-S conjugate $\beta$-lyase activities and determined their ability to transform the $4 \mathrm{MMP}$ precursor into the aroma compound $4 \mathrm{MMP}$ for future applications.

\section{Materials and Methods}

\subsection{Synthesis of the Precursor cys-4MMP}

All reagents were purchased from commercial sources. Flash chromatography was performed with SiliCycle silica gel 70-230 mesh (product number: R10040B). Thin-layer chromatography (TLC) was carried out on precoated silica plates (Merck cat. 1.05554). The cys-4MMP synthesis reaction process and the fractions from flash chromatography were monitored by TLC (EA/ethanol/distilled water $=4 / 2 / 1)$ and developed with $0.5 \%$ ninhydrin in acetone.

For the chemical structure verification by NMR, ${ }^{1} \mathrm{H}$ NMR $\left(600 \mathrm{MHz} ; \mathrm{D}_{2} \mathrm{O}\right)$ spectrum shows the following signals: $\delta=1.41\left(\mathrm{~s}, 2 \times \mathrm{CH}_{3}\right), 2.25\left(3 \mathrm{H}, \mathrm{s}, \mathrm{C}(\mathrm{O}) \mathrm{CH}_{3}\right), 2.83(1 \mathrm{H}, \mathrm{d}$, $\left.J=15.4 \mathrm{~Hz}, \mathrm{C}(\mathrm{O}) \mathrm{C}_{\mathrm{A}} \mathrm{H}_{\mathrm{B}}\right), 2.88\left(1 \mathrm{H}, \mathrm{d}, J=15.4 \mathrm{~Hz}, \mathrm{CH}_{\mathrm{A}} \underline{\mathrm{H}}_{\mathrm{B}}\right), 3.05(1 \mathrm{H}, \mathrm{dd}, J=7.8$ and 13.8 $\left.\mathrm{Hz}, \mathrm{SC}_{\mathrm{A}} \mathrm{H}_{\mathrm{B}}\right), 3.18\left(1 \mathrm{H}, \mathrm{dd}, J=4.2\right.$ and $\left.13.8 \mathrm{~Hz}, \mathrm{SCH}_{\mathrm{A}} \underline{\mathrm{H}}_{\mathrm{B}}\right)$, and $3.92(1 \mathrm{H}, \mathrm{dd}, J=4.2$ and $7.8 \mathrm{~Hz}, \mathrm{H}_{2} \mathrm{NC}$ ). In addition, ${ }^{13} \mathrm{C}$ NMR spectrum shows $\delta=27.9,28.0,28.6,31.7,44.1$, $53.5,54.2,172.5$, and 213.5. For high-resolution mass spectrometry analysis, the theoretical molecular weight of $\mathrm{C}_{9} \mathrm{H}_{17} \mathrm{NO}_{3} \mathrm{~S}(\mathrm{M}+\mathrm{H})$ is 220.1007 , and the detected signal is at 220.0925 . 


\subsection{Liquid Chromatography-Mass Spectrometry}

In order to identify the $4 \mathrm{MMP}$ converted from cys-4MMP in the extract samples, the chemical derivatization was performed to generate a stable form of 4MMP-DTDP (4,4-dithiodipyridine) for subsequent mass spectrometry analysis. The chemical derivatized extract samples were subjected to LTQ (linear trap quadropole) mass spectrometer (Thermo Fisher, Waltham, MA, USA) coupled with an Agilent 1100 HPLC and Famos autosampler system (Agilent Technologies, Santa Clara, CA, USA). Instrument control, data acquisition, and analysis were performed using Thermo Xcalibur (ver. 2.2). Chromatographic separation was achieved on an XBridge C18 (1.0 $\times 150 \mathrm{~mm}, 3.5 \mu \mathrm{m})$ column with the column temperature set at $35^{\circ} \mathrm{C}$. The mobile phase consisted of solvent $\mathrm{A}(0.1 \%$ formic acid in the water) and solvent $\mathrm{B}(0.1 \%$ formic acid in $80 \%$ acetonitrile). The gradient was set as follows: $2 \%$ B for $3.0 \mathrm{~min}$, increased to $80 \%$ at $18 \mathrm{~min}$, increased further to $98 \%$ at $18.5 \mathrm{~min}$ and maintained for $1.5 \mathrm{~min}$, then decreased to $2 \%$ at $20 \mathrm{~min}$, followed by $10 \mathrm{~min}$ equilibration. The flow rate of mobile phases was $0.05 \mathrm{~mL} / \mathrm{min}$. The LTQ mass spectrometer was operated at positive mode with the following parameters: spray voltage, $4.0 \mathrm{kV}$; heated capillary, $275^{\circ} \mathrm{C}$; sheath gas pressure, $10 \mathrm{psi}$. For both full mass and MS/MS scans, spectra were acquired in the range of $m / z 100$ to 400 . For the quantification of 4MMP-DTDP, the quantity of 4MMP-DTDP in each sample was determined by the extracted ion chromatogram of 4MMP-DTDP product ion at $m / z 144.0$ with the precursor ion at $m / z 242.0$ in MS/MS analysis.

\subsection{Nuclear Magnetic Resonance Spectroscopy}

NMR experiments were carried out at $298 \mathrm{~K}$ on Bruker Avance $600 \mathrm{MHz}$ NMR spectrometers equipped with $5 \mathrm{~mm}$ triple resonance cryoprobe and Z-gradient. The data were acquired and processed using the software Topspin 2.1 (Bruker, Bremen, Germany). ${ }^{1} \mathrm{H}$ and ${ }^{13} \mathrm{C}$ chemical shifts were calibrated using methanol- $\mathrm{d}_{4}$ as the internal reference at 3.31 and 19.15 ppm, respectively. $1 \mathrm{D}^{1} \mathrm{H}$ NMR, $1 \mathrm{D}^{13} \mathrm{C}$ NMR, and 2D HSQC (heteronuclear single quantum coherence) spectra were performed for the compound structure validation.

\subsection{Bacterial and Yeast Strains and Their Cultivation}

The bacterial strains, such as B. subtilis BCRC 10255, E. limosum BCRC 14401, Lb. casei BCRC 10697, Lb. delbrueckii subsp. bulgaricus BCRC 10696, and S. putrefaciens BCRC 10596, and the yeast strains Debaryomyces hansenii BCRC 21394, Kluyveromyces lactis BCRC 21337, Kluyveromyces marxianus BCRC 21363, chizosaccharomyces pombe BCRC 20331, and Saccharomyces cerevisiae BCRC 21584, 21685, and 21686 were purchased from Bioresources Collection and Research Center (BCRC) in Hsinchu, Taiwan. B. subtilis was cultured in LB-broth (Foremedium, Hunstanton, Norfolk, UK); E. limosum was cultured in modified peptone yeast glucose medium; $L b$. casei and $L b$. delbrueckii subsp. bulgaricus were cultured in lactobacilli MRS broth (Becton, Dickinson and Company, Sparks, NV, USA); S. putrefaciens was cultured in tryptic soy broth (Becton, Dickinson and Company, Sparks, NV, USA). The yeast cells were in commercial yeast extract-peptone-dextrose (YPD) medium (Foremedium, Hunstanton, Norfolk, UK) for cultivation.

\subsection{Preparation of Bacterial and Yeast Cell Extracts}

Bacterial and yeast cell extracts were freshly prepared and used for the determination of $\beta$-lyase activity, as previously described with some modifications [21]. Cells were cultivated until an OD600 of 0.8 and centrifuged at $5000 \times g$ for $5 \mathrm{~min}$. The supernatant was discarded, and the pelleted cells were re-suspended in $\mathrm{pH} 7$ phosphate buffer containing $30.75 \mathrm{mM} \mathrm{K}_{2} \mathrm{HPO}_{4}, 19.25 \mathrm{mM} \mathrm{KH}_{2} \mathrm{PO}_{4}, 1 \mathrm{mM}$ EDTA, $20 \mathrm{mM}$ pyroxidal phosphate, and $10 \%$ glycerol. The re-suspended cells were sonicated to disrupt the cell membrane, centrifuged at $20,000 \times \mathrm{g}$ at $4{ }^{\circ} \mathrm{C}$ for $20 \mathrm{~min}$ to remove cell debris, and the supernatant was collected as the cell extract. 


\section{6. $\beta$-lyase Activity Assays}

The $\beta$-lyase activity of the cell extracts was determined by measuring the absorbance of the product formed by the spontaneous disulfide interchange between free thiol groups and 5,5'-dithiobis(2-nitrobenzoic acid) (DTNB), as described previously [22]. Various substrates, such as L-cystathionine, L-cystine, L-methionine, and cys-4MMP, were added into $\mathrm{pH} 8$ phosphate buffer containing $100 \mathrm{mM}$ sodium phosphate, $1 \mathrm{mM}$ EDTA, $20 \mathrm{mM}$ pyridoxal- $5^{\prime}$-phosphate, and crude cell extracts ( $4 \times$ dilution), individually, to reach a final substrate concentration of $1 \mathrm{mM}$. The reaction solution was incubated for $30 \mathrm{~min}$ at RT, and $5 \mu \mathrm{L}$ of the reaction solution was taken out to mix with $50 \mu \mathrm{L} \mathrm{pH} 8$ phosphate buffer, which contains $100 \mathrm{mM}$ sodium phosphate, $1 \mathrm{mM}$ EDTA, and $1 \mu \mathrm{L}$ DTNB. The absorbance of the mixture was measured at a wavelength of $412 \mathrm{~nm}$ with a spectrophotometer. The rate of $\beta$-lyase activity was calculated by using cysteine as the standard in the assay. Each enzyme activity unit $(\mathrm{U})$ represents the formation of $1 \mu \mathrm{M}$ L-cysteine per minute. In this study, we measured the $\beta$-lyase activity of the cell extracts at different temperatures $(20,30$, and $\left.37^{\circ} \mathrm{C}\right)$ and $\mathrm{pH}(3.5,4.5,5.5$, and 7$)$ to evaluate the effects of temperature and $\mathrm{pH}$ on enzyme activity.

\subsection{Determination of 4-MMP by Liquid Chromatography-Mass Spectrometry}

In order to determine the amount of 4-MMP converted from cys-4MMP by $\beta$-lyase, 4-MMP was chemically derivatized with DTDP for liquid chromatography-mass spectrometry analysis according to a previous study by Capone et al. [23]. Cell extracts containing 4-MMP were added with freshly thawed DTDP (final concentration of $400 \mu \mathrm{M}$ ) and EDTA (final concentration of $10 \mathrm{mM}$ ) and incubated at RT for $30 \mathrm{~min}$. Samples were passed through $6 \mathrm{~mL}, 500 \mathrm{mg}$ ProElut ${ }^{\mathrm{TM}} \mathrm{C} 18$ cartridges (previously activated with $6 \mathrm{~mL}$ of methanol and $6 \mathrm{~mL}$ of water). The cartridges were washed with $12 \mathrm{~mL}$ of $50 \%$ methanol, dried under air for $5 \mathrm{~min}$, and then eluted with $3 \mathrm{~mL}$ of methanol. The elution solution was stored at $4{ }^{\circ} \mathrm{C}$ and ready for LC-MS analysis.

\subsection{Statistical Analysis}

Data were statistically analyzed using SPSS Version 12.0 (SPSS Inc., Chicago, IL, USA). One-way analysis of variance (ANOVA) was used to determine the statistical differences between the sample means, with the level of significance set at $p<0.05$. Multiple comparisons of the means were conducted using the Tukey test. All data are expressed as mean $\pm \mathrm{SD}$.

\section{Results and Discussion}

\subsection{Cys-4MMP Synthesis}

The syntheses of cys-4MMP (also known as (2R)-S-(1,1-dimethyl-3-oxobutyl-cysteine), (R)-2-amino-3-(2-methyl-4-oxo-pentan-2-ylthio) propanoic acid, and S-4-(4-mercapto-4methylpentan-2-one)-L-cysteine)) and its deuterated analog had been reported $[8,24,25]$. The structure of cys-4MMP was firstly identified by Tominaga et al. [8] using gas chromato graphy-mass spectrometry (GC-MS) and further confirmed using ${ }^{1} \mathrm{H}$ and ${ }^{13} \mathrm{C}$ NMR spectroscopy by Starkenmann [24] and Hebditch et al. [25]. However, previous synthesis methods encountered difficulties in separating the desired product from unreacted cysteine or involving 1,4-dioxane, a toxic and unfriendly environmental organic solvent $[8,24,25]$. Cysteine-conjugates can be obtained by treating cysteine with $\alpha$,-unsaturated carbonyl compounds under alkaline conditions. To meet the potential requirements of further studies, we used the Michael addition of cysteine to mesityl oxide (2, Scheme 1) (as shown in Section 3.1) to synthesize cys-4MMP and isolated it from the reaction mixture by flash chromatography with normal phase silica gel and a proper solvent system. For chemical structure characterization of cys-4MMP as shown in Figure 1, the base peak at $m / z 220$ corresponds to the molecular formula $\mathrm{C}_{9} \mathrm{H}_{17} \mathrm{NO}_{3} \mathrm{~S}$, the $[\mathrm{M}+\mathrm{H}]$ ion of 3 . In addition to the mass data, the NMR spectrum (Figure 2) closely coincided with the proposed structure revealed in the literature. Compared with other synthetic methods, our method is an 
environmentally friendly and economical method with a higher yield and potential for large-scale production (Supplementary Table S1). To the best of our knowledge, we are the first to report a pure cys-4MMP (spectrum grade) with a yield of $29.7-35 \%$, evident by the NMR and LC-MS data.<smiles>N[C@@H](CS)C(=O)O</smiles>

1

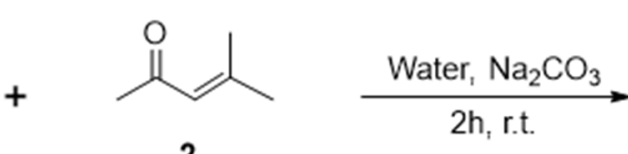

2<smiles>CC(=O)CC(C)(C)SCC(N)C(=O)O</smiles>

Scheme 1. L-cysteine hydrochloride $1(2.81 \mathrm{~g}$, $16 \mathrm{mmole})$ was dissolved in $10 \mathrm{~mL}$ of distilled water, and $16 \mathrm{~mL}$ of $1 \mathrm{M} \mathrm{Na}_{2} \mathrm{CO}_{3}$ solution was added dropwise to the mixture with stirring to adjust the $\mathrm{pH}$ to 8 . Then, mesityl oxide 2 (1.57 $\mathrm{g}, 16 \mathrm{mmole})$ was added, and the mixture was stirred at room temperature for $2 \mathrm{~h}$. After the reaction mixture was washed with diethyl ether, the aqueous layer was concentrated under vacuum at $40{ }^{\circ} \mathrm{C}$ and then subjected to flash column chromatography (eluent: EA/ethanol/distilled water $=4 / 2 / 1$ ) to obtain the product cys-4MMP 3 . The product was further purified via recrystallization (1.04 $\mathrm{g}$, yield $29 \%$ ).

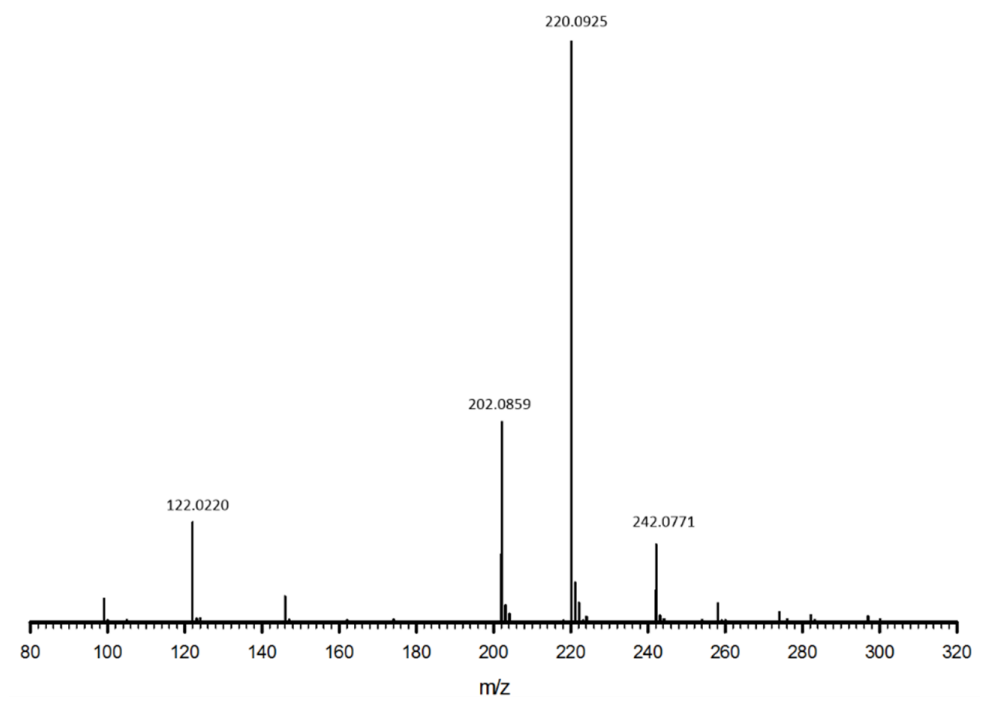

Figure 1. Mass spectrum of synthetic cysteine monoadduct 3 (cys-4MMP).

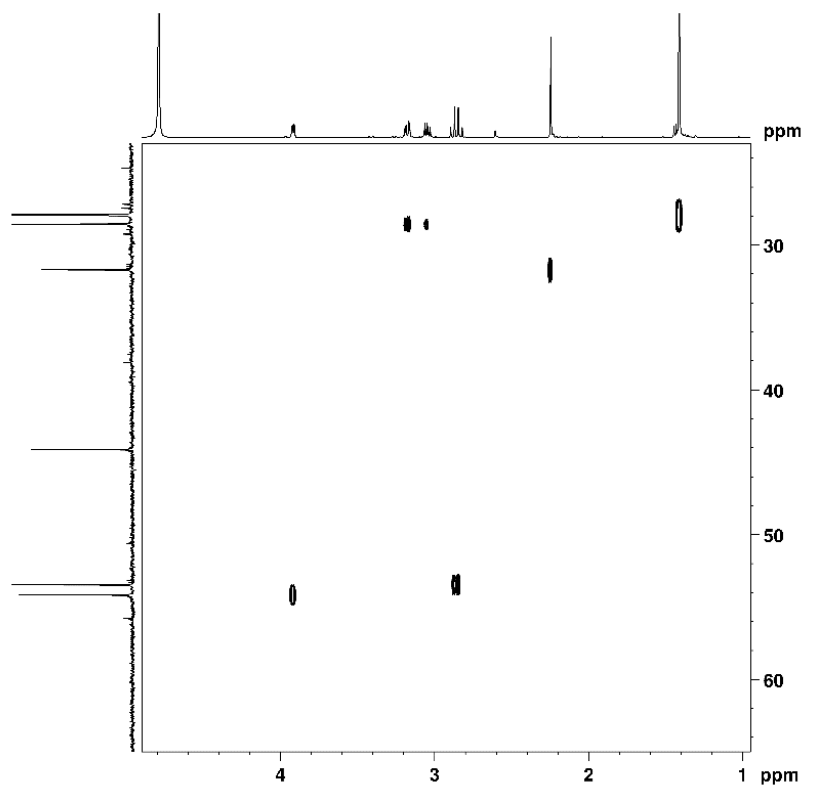

Figure 2. ${ }^{1} \mathrm{H}-{ }^{13} \mathrm{C}$ HSQC NMR spectrum of cysteine monoadduct 3 (cys-4MMP). 


\subsection{Screening of Yeast Extracts for $\beta$-lyase Activities}

For the yeast extracts screening, we surveyed the food-related yeast families, such as Saccharomycetaceae and Schizosaccharomycetaceae, and we selected food-related yeast strains, such as S. cerevisiae, D. hansenii, K. lactis, and K. marxianus from Saccharomycetaceae, and Schizo. pombe from Schizosaccharomycetaceae. In addition, we looked into the NCBI database to confirm that the selected yeast strains encode identified/putative cysteine-Sconjugate $\beta$-lyases.

Most thioamino acids can be used as substrates for carbon-sulfur $\beta$-lyases [11,26]; therefore, three different types of thiol-containing amino acids were selected as substrates to test $\beta$-lyase activity of the cell extracts from different microbial strains in this study. The $\beta$-lyase activities to L-cystathionine, L-cystine, and L-methionine in the presence of seven different yeast extracts were measured and summarized in Figure 4. For the $\beta$-lyase activity against L-cystathionine, the cell extracts from Saccharomyces cerevisiae 21584 and Kluyveromyces lactis exhibited the highest $\beta$-lyase activities of $70.72 \pm 7.92$ and $69.57 \pm 4.64 \mathrm{U} / \mathrm{mL}$, respectively, followed by the cell extracts from Schizosaccharomyces pombe and S. cerevisiae 21685 , with $\beta$-lyase activities of $57.20 \pm 2.68$ and $52.56 \pm 5.36 \mathrm{U} / \mathrm{mL}$, respectively. S. cerevisiae 21584 and K. lactis also exhibited the highest specific activities against L-cystathionine, which were $27.63 \pm 3.09$ and $27.17 \pm 1.81 \mathrm{U} / \mathrm{mg}$, respectively, and these were followed by the cell extracts from Schizo. pombe and S. cerevisiae 21685, with specific activities of $22.34 \pm 1.05$ and $22.19 \pm 2.72 \mathrm{U} / \mathrm{mg}$, respectively (Table 1 ).

Table 1. The $\beta$-lyase activities for various substrates by various yeast crude extracts.

\begin{tabular}{|c|c|c|c|c|c|c|}
\hline \multirow[b]{2}{*}{ Yeasts } & \multicolumn{2}{|c|}{ L-Cystathionine } & \multicolumn{2}{|c|}{ L-Cystine } & \multicolumn{2}{|c|}{ L-Methionine } \\
\hline & $\begin{array}{c}\beta \text {-Lyase } \\
\text { Activity } \\
(\mathrm{U} / \mathrm{mL})\end{array}$ & $\begin{array}{c}\text { Specific } \\
\text { Activities } \\
\text { (U/mg Protein) }\end{array}$ & $\begin{array}{l}\beta \text {-Lyase } \\
\text { Activity } \\
(\mathrm{U} / \mathrm{mL})\end{array}$ & $\begin{array}{c}\text { Specific } \\
\text { Activities } \\
\text { (U/mg Protein) }\end{array}$ & $\begin{array}{l}\beta \text {-Lyase } \\
\text { Activity } \\
(\mathrm{U} / \mathrm{mL})\end{array}$ & $\begin{array}{c}\text { Specific } \\
\text { Activities } \\
\text { (U/mg Protein) }\end{array}$ \\
\hline \multicolumn{7}{|l|}{ S. cerevisiae } \\
\hline 21584 & $70.72 \pm 7.92^{\mathrm{a}}$ & $27.63 \pm 3.09^{a}$ & $22.26 \pm 2.41^{\mathrm{a}}$ & $8.70 \pm 0.94^{\mathrm{a}}$ & $44.87 \pm 2.09^{b}$ & $17.53 \pm 0.82^{b}$ \\
\hline 21685 & $56.81 \pm 6.96^{b}$ & $22.19 \pm 2.72^{b}$ & $13.57 \pm 2.09$ cde & $5.30 \pm 0.82^{b}$ & $40.70 \pm 2.09 \mathrm{bc}$ & $15.90 \pm 0.81^{b c}$ \\
\hline 21686 & $12.75 \pm 2.40^{c}$ & $6.54 \pm 1.19^{c}$ & $12.52 \pm 0.00^{b c}$ & $6.42 \pm 0.00^{b}$ & $10.43 \pm 2.41^{\mathrm{e}}$ & $5.35 \pm 1.24^{\mathrm{e}}$ \\
\hline K. marxianus & $52.56 \pm 5.36^{b}$ & $20.53 \pm 2.09^{b}$ & $15.30 \pm 2.41^{\mathrm{de}}$ & $5.98 \pm 0.94^{b}$ & $37.57 \pm 3.41^{\mathrm{c}}$ & $14.67 \pm 1.33^{c}$ \\
\hline K. lactis & $69.57 \pm 4.64^{\mathrm{a}}$ & $27.17 \pm 1.81^{\mathrm{a}}$ & $13.91 \pm 4.82^{\mathrm{bcd}}$ & $5.43 \pm 1.88^{b}$ & $60.52 \pm 7.23^{a}$ & $23.64 \pm 2.82^{a}$ \\
\hline D. hansenii & $17.01 \pm 7.08^{c}$ & $5.64 \pm 2.77^{c}$ & $22.96 \pm 14.76^{\mathrm{e}}$ & $8.97 \pm 5.76^{a}$ & $25.04 \pm 7.62^{d}$ & $9.78 \pm 2.98^{d}$ \\
\hline Schizo. pombe & $57.20 \pm 2.68^{b}$ & $22.34 \pm 1.05^{b}$ & $23.65 \pm 2.41^{a b}$ & $9.24 \pm 0.94^{\mathrm{a}}$ & $63.65 \pm 6.26^{\mathrm{a}}$ & $24.86 \pm 2.45^{\mathrm{a}}$ \\
\hline
\end{tabular}

Values are expressed as mean \pm standard deviation $(n=3)$. Different superscript lower case letters in the same column indicate significant differences $(p<0.05)$.

For the $\beta$-lyase activity against L-cystine, the cell extracts from Schizo. pombe and S. cerevisiae 21584 exhibited the highest $\beta$-lyase activities of $23.65 \pm 2.41$ and $22.26 \pm 2.41 \mathrm{U} / \mathrm{mL}$, respectively. Schizo. pombe and S. cerevisiae 21584 also exhibited the highest specific activities against L-cystine of $9.24 \pm 0.94$ and $8.70 \pm 0.94 \mathrm{U} / \mathrm{mg}$, respectively. For the $\beta$-lyase activity against L-methionine, the cell extracts from Schizo. pombe and K. lactis exhibited the highest $\beta$-lyase activities of $63.65 \pm 6.26$ and $60.52 \pm 7.23 \mathrm{U} / \mathrm{mL}$, respectively, followed by the cell extracts from S. cerevisiae 21584 and 21685, with $\beta$-lyase activities of $44.87 \pm 2.09$ and $40.70 \pm 2.09 \mathrm{U} / \mathrm{mL}$, respectively. Schizo. pombe and K. lactis exhibited the highest specific activities against L-methionine of $24.86 \pm 2.45$ and $23.64 \pm 2.82 \mathrm{U} / \mathrm{mg}$, respectively, followed by the cell extracts from S. cerevisiae 21584 at $17.53 \pm 0.82 \mathrm{U} / \mathrm{mg}$.

It has been reported that $S$. cerevisiae $\beta$-lyase has a wide selection of substrates. Holt et al. [27] demonstrated that the purified recombinant S. cerevisiae Str3p had a $\beta$-lyase activity on seven sulfur-containing substrates, including L-cystathionine, L-djenkolate, L-cystine, S-ethyl-L-cysteine, S-methyl-L-cysteine, L-cysteine, and L-methionine. Their results indicated that $S$. cerevisiae $S \operatorname{str} p$ had a relatively higher $\beta$-lyase activity against L-djenkolate $(154 \% \pm 11.0 \%)$ and L-cystathionine $(100 \% \pm 10.9 \%)$, but showed a lower activity against L-cystine $(22.0 \% \pm 2.1 \%)$, S-ethyl-L-cysteine $(9.0 \% \pm 0.7 \%)$, and S-methyl- 
L-cysteine $(7.4 \% \pm 0.3 \%)$. Our data indicate that S. cerevisiae 21584 , Schizo. pombe, and K. lactis showed the best $\beta$-lyase activity against the tested compounds. Additionally, the cell extracts from most yeast strains showed a higher $\beta$-lyase activity for L-cystathionine. As a result, the cell extracts from $S$. cerevisiae 21584, Schizo. pombe, and K. lactis were selected for subsequent experiments.

\subsection{Screening of Bacterial Extracts for $\beta$-lyase Activities}

We surveyed some bacteria families related to food production and spoilage, such as Bacillaceae, Lactobacillaceae, Eubacteriaceae, and Shewanellaceae, and we chose B. subtlis from Bacillaceae, E. limosum from Eubacteriaceae, Lb. bulgaricus and Lb. casei from Lactobacillaceae, and S. putrefaciens from Shewanellaceae. In addition, we looked into the NCBI database to confirm that the selected bacteria strains encode identified/putative cysteine-S-conjugate $\beta$-lyases.

As shown in Table 2, the $\beta$-lyase activities of the five bacterial extracts were tested. For the $\beta$-lyase activity against L-cystathionine, the cell extracts from $S$. putrefaciens exhibited the highest $\beta$-lyase activity of $305.46 \pm 25.66 \mathrm{U} / \mathrm{mL}$, which was followed by $L b$. casei with a $\beta$-lyase activity of $40.19 \pm 2.68 \mathrm{U} / \mathrm{mL}$. S. putrefaciens also exhibited the highest specific activity of $41.84 \pm 3.51 \mathrm{U} / \mathrm{mg}$ against L-cystathionine and the cell extracts from $\mathrm{Lb}$. casei followed it with a specific activity of $11.48 \pm 0.77 \mathrm{U} / \mathrm{mg}$. For the $\beta$-lyase activity against L-cystine, the cell extracts from $S$. putrefaciens exhibited the highest $\beta$-lyase activity of $207.62 \pm 22.98 \mathrm{U} / \mathrm{mL}$ and specific activity of $25.60 \pm 2.83 \mathrm{U} / \mathrm{mg}$. For the $\beta$-lyase activity against L-methionine, the cell extracts from $S$. putrefaciens exhibited the highest $\beta$-lyase activity of $184.33 \pm 10.76 \mathrm{U} / \mathrm{mL}$, followed by the cell extracts from $L b$. casei with a $\beta$-lyase activity of $32.46 \pm 4.64$. S. putrefaciens exhibited the highest specific activity against Lmethionine of $22.73 \pm 1.33 \mathrm{U} / \mathrm{mg}$, followed by the cell extracts from $\mathrm{Lb}$. casei with a $\beta$-lyase activity of $8.35 \pm 1.79 \mathrm{U} / \mathrm{mg}$ protein.

Table 2. The $\beta$-lyase activities for various substrates by various bacteria crude extracts.

\begin{tabular}{|c|c|c|c|c|c|c|}
\hline \multirow[b]{2}{*}{ Bacteria } & \multicolumn{2}{|c|}{ L-Cystathionine } & \multicolumn{2}{|c|}{ L-Cystine } & \multicolumn{2}{|c|}{ L-Methionine } \\
\hline & $\begin{array}{c}\beta \text {-Lyase } \\
\text { Activity } \\
(\mathrm{U} / \mathrm{mL})\end{array}$ & $\begin{array}{c}\text { Specific } \\
\text { Activities } \\
\text { (U/mg Protein) }\end{array}$ & $\begin{array}{c}\beta \text {-Lyase } \\
\text { Activity } \\
(\mathrm{U} / \mathrm{mL})\end{array}$ & $\begin{array}{c}\text { Specific } \\
\text { Activities } \\
\text { (U/mg Protein) }\end{array}$ & $\begin{array}{l}\beta \text {-Lyase } \\
\text { Activity } \\
(\mathrm{U} / \mathrm{mL})\end{array}$ & $\begin{array}{c}\text { Specific } \\
\text { Activities } \\
\text { (U/mg Protein) }\end{array}$ \\
\hline B. subtilis & $27.99 \pm 2.75^{c}$ & $8.49 \pm 0.84^{c}$ & $29.58 \pm 4.77^{b}$ & $8.08 \pm 1.30^{b}$ & $21.63 \pm 2.75^{c}$ & $5.91 \pm 0.75^{c}$ \\
\hline E. limosum & $13.91 \pm 8.03^{\mathrm{d}}$ & $7.14 \pm 4.12^{b}$ & $6.96 \pm 3.28^{c}$ & $3.21 \pm 1.51^{\mathrm{c}}$ & $12.37 \pm 5.36^{c}$ & $5.71 \pm 2.47^{b}$ \\
\hline Lb. bulgaricus & $23.95 \pm 5.93^{c}$ & $7.54 \pm 1.86^{c}$ & $32.50 \pm 2.96^{b}$ & $9.20 \pm 0.84^{b}$ & $13.68 \pm 2.96^{c}$ & $3.88 \pm 0.84^{c}$ \\
\hline Lb. casei & $40.19 \pm 2.68^{b}$ & $11.48 \pm 0.77^{b}$ & $27.83 \pm 4.64^{b}$ & $7.16 \pm 1.19^{b}$ & $32.46 \pm 4.64^{b}$ & $8.35 \pm 1.19^{b}$ \\
\hline S. putrefaciens & $305.46 \pm 25.66^{a}$ & $41.84 \pm 3.51^{\mathrm{a}}$ & $207.62 \pm 22.98^{a}$ & $25.60 \pm 2.83^{a}$ & $184.33 \pm 10.76^{a}$ & $22.73 \pm 1.33^{a}$ \\
\hline
\end{tabular}

Values are expressed as mean \pm standard deviation $(n=3)$. Different superscript lower case letters in the same column indicate significant differences $(p<0.05)$.

Our data show that the cell extracts from S. putrefaciens and Lb. casei have relatively high $\beta$-lyase activities on the three tested sulfur-containing substrates. In addition, the conversion efficiency of L-cystathionine of both $S$. putrefaciens and Lb. casei was higher than that of L-cystine and L-methionine. This observation was similar to previous reports, suggesting that the catalytic efficiency of L-methionine by Lactococcus $\beta$-lyase was approximately 100 times lower than that of L-cystathionine [28,29]. Additionally, despite the poor conversion efficiency in our study, it has been reported that the cysteine-S-conjugate precursor could convert into the sulfur-containing aroma compound $4 \mathrm{MMP}$ by reacting with E. limosum cell extract [8]. As a result, we selected the cell extracts from S. putrefaciens, $L b$. casei, and E. limosum for subsequent $\beta$-lyase activity experiments.

Cysteine-S-conjugate $\beta$-lyase and cystathionine $\beta$-lyase are cellular metabolic enzymes involved in sulfur-containing amino acid biosynthesis, and previous studies have indicated that the addition of cysteine and methionine in culture media could have diverse impacts on their expression or activity in different microbial strains. In Shewanella oneidensis, the addition of cysteine could increase the gene expression of the cystathionine $\beta$-lyase 
MetC [30]. On the other hand, the expression of cystathionine $\beta$-lyase in Lactococcus lactis was negatively regulated by high concentrations of glutathione, cysteine, and methionine in the culture medium, while sulfur limitation could result in a high level of the $\beta$-lyase expression [31]. Further researches to improve the amount of cysteine-S-conjugate $\beta$-lyases in the cell extracts should be optimized for different microbial strains.

\subsection{Optimized Temperature for Yeast and Bacterial Extracts for $\beta$-lyase Activities}

Typical foods on the market are primarily acidic and neutral foods. Thus, considering that the $\mathrm{pH}$ applied to food in the future may affect the $\beta$-lyase activity in yeast and bacterial cell extracts, several possible food $\mathrm{pH}$ applications were selected, such as grape juice or wine ( $\mathrm{pH} 3.0-3.5)$, sake ( $\mathrm{pH} 4.5)$, and coffee or beer ( $\mathrm{pH}$ 5.2-5.6), to explore the effect of $\mathrm{pH}$ on the $\beta$-lyase activity. To study the effect of temperature and $\mathrm{pH}$ on the activity of $\beta$-lyase in yeast and bacterial cell extracts, L-cystathionine was used as the substrate for the determination of $\beta$-lyase activity. As shown in Figure 3, the $\beta$-lyase activities of the yeast cell extracts from S. cerevisiae 21584, K. lactis, and Schizo. pombe were measured at 20, 25,30 , and $37^{\circ} \mathrm{C}$ and $\mathrm{pH} 3.5,4.5,5.5$, and 7 . The cell extract from S. cerevisiae 21584 showed higher $\beta$-lyase activity at acidic $\mathrm{pH}$, but different temperatures seemed to not affect $\beta$-lyase activity (Figure $3 \mathrm{~A}$ ). The $K$. lactis cell extract showed a relatively higher $\beta$-lyase activity at $\mathrm{pH} 3.5$ and at 20 and $25^{\circ} \mathrm{C}$ (Figure 3B). The cell extract from Schizo. pombe exhibited a higher $\beta$-lyase activity at $\mathrm{pH} 4.5$ and 5.5; in addition, there was no significant difference in $\beta$-lyase activity at different temperatures (Figure 3C). Intriguingly, Zha et al. [16] found that the optimum temperature and $\mathrm{pH}$ for the $\beta$-lyase activity of the recombinant STR3 protein from S. cerevisiae were $50^{\circ} \mathrm{C}$ and 8 , respectively. Because the whole-cell extract instead of purified recombinant protein was used for $\beta$-lyase activity, the different results between the pure recombinant S. cerevisiae STR3 [16] and our S. cerevisiae 21584 cell extract may be because the cell extract contains other enzymes that also contribute to the release of thiol groups. Therefore, the overall optimum temperature and $\mathrm{pH}$ may be different.

The effects of temperature and $\mathrm{pH}$ on the $\beta$-lyase activities of bacterial cell extracts from E. limosum, Lb. casei, and S. putrefaciens were also investigated. As shown in Figure 4, the cell extract from E. limosum showed higher $\beta$-lyase activity at $\mathrm{pH} 3.5$ at all temperatures (Figure 4A). Additionally, temperatures seemed to have no significant effect on the $\beta$-lyase activity. The $\beta$-lyase activities of the cell extract from $L b$. casei did not show significant differences at various $\mathrm{pH}$ values and temperatures, although it had a relatively lower activity at $\mathrm{pH} 3.5$ and $25^{\circ} \mathrm{C}$ (Figure 4B). The cell extract from S. putrefaciens showed higher $\beta$-lyase activity at $\mathrm{pH} 7$, and the $\beta$-lyase activity decreased with the decreasing $\mathrm{pH}$. Additionally, the $\beta$-lyase activity seemed stable in the temperature range of 20 to $37^{\circ} \mathrm{C}$. Our data indicate that the cell extracts showed significant differences in substrate specificity and optimum reaction $\mathrm{pH}$. 


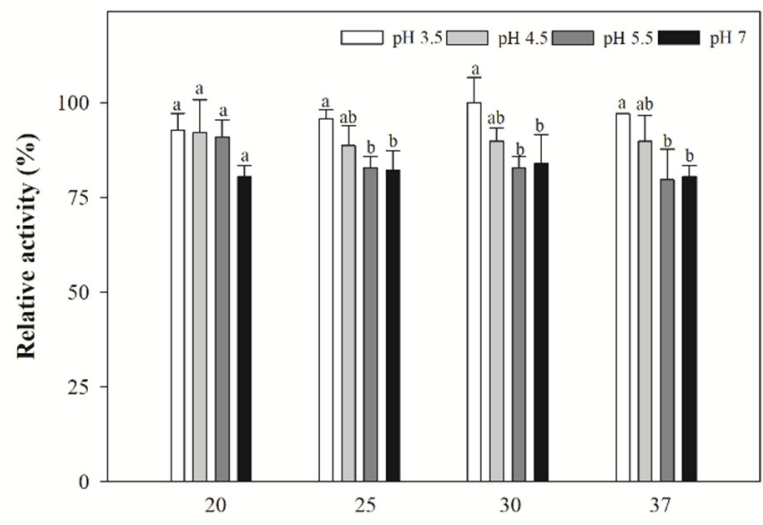

(a)

Temperature $\left({ }^{\circ} \mathrm{C}\right)$

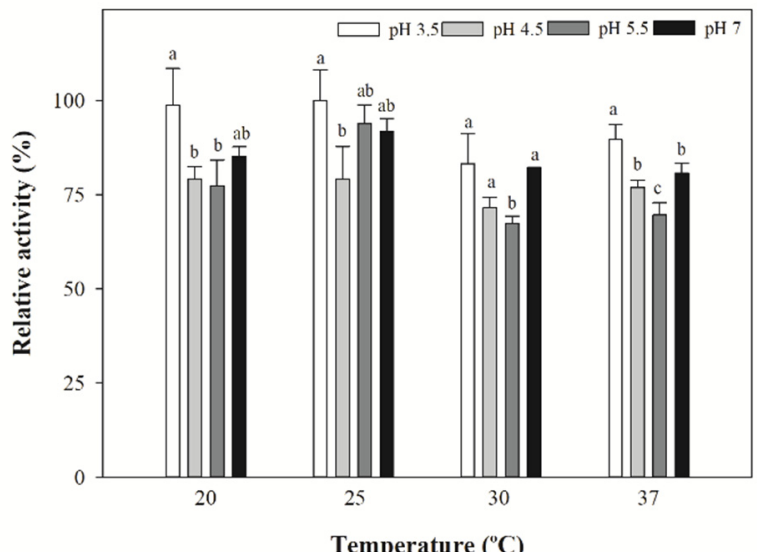

(b)

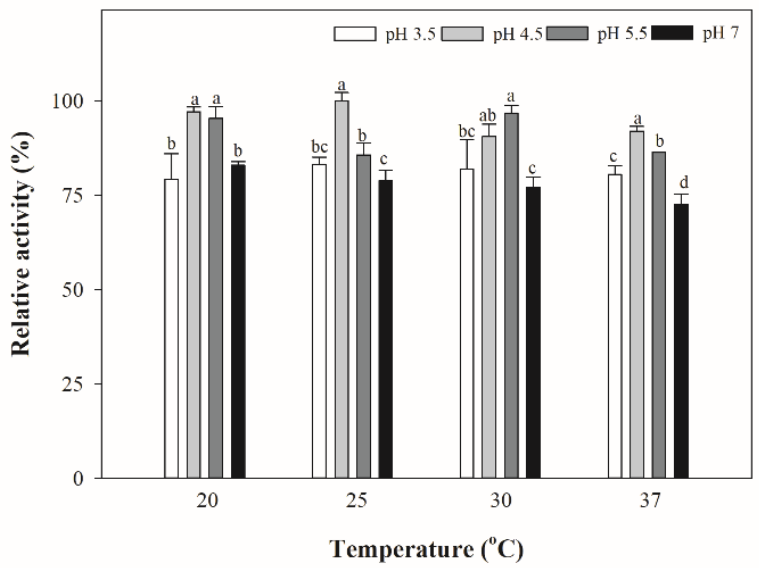

Figure 3. The $\beta$-lyase activity of (a) S. cerevisiae 21584, (b) K. lactis, and (c) Schizo. pombe yeast extracts at various temperatures and $\mathrm{pH}$. The $\mathrm{C}$-S $\beta$-lyase specific activities were determined by the DTNB assay using $1 \mathrm{mM}_{\mathrm{L}}$-cystathionine at 20,2530 , and $37^{\circ} \mathrm{C}$, and at $\mathrm{pH}$ values of 3.5, 4.5, 5.5, and 7.0. Relative activity of $100 \%$ represented the highest value among all the specific activities in different temperatures and $\mathrm{pH}$. Data are expressed as mean \pm standard deviation $(n=3)$. Different lower case letters in the same grouped bars indicate significant differences $(p<0.05)$. 


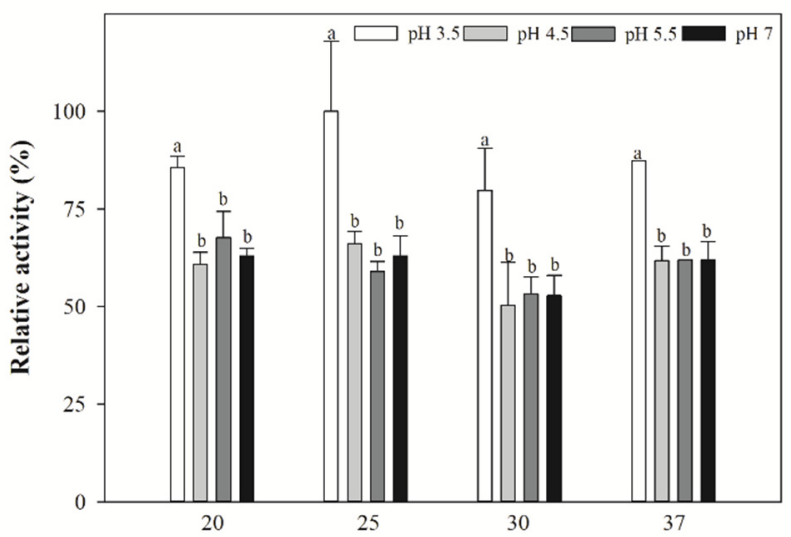

(a)

Temperature $\left({ }^{\circ} \mathrm{C}\right)$

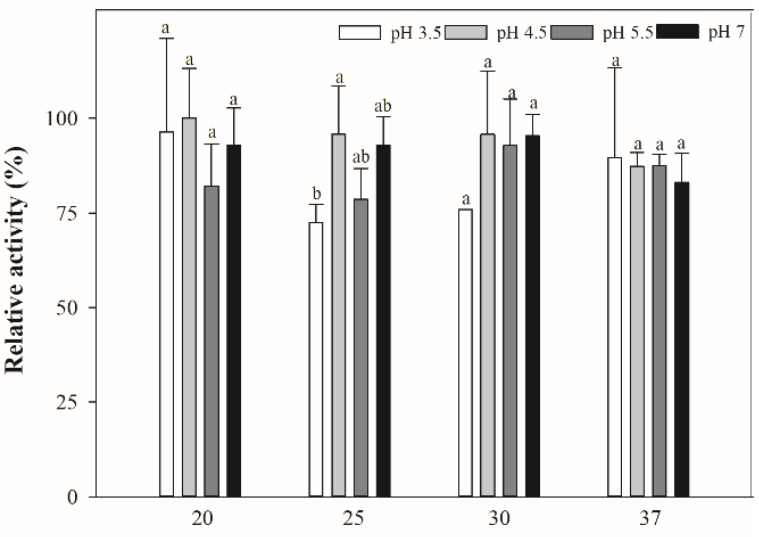

(b)

Temperature $\left({ }^{0} \mathrm{C}\right)$

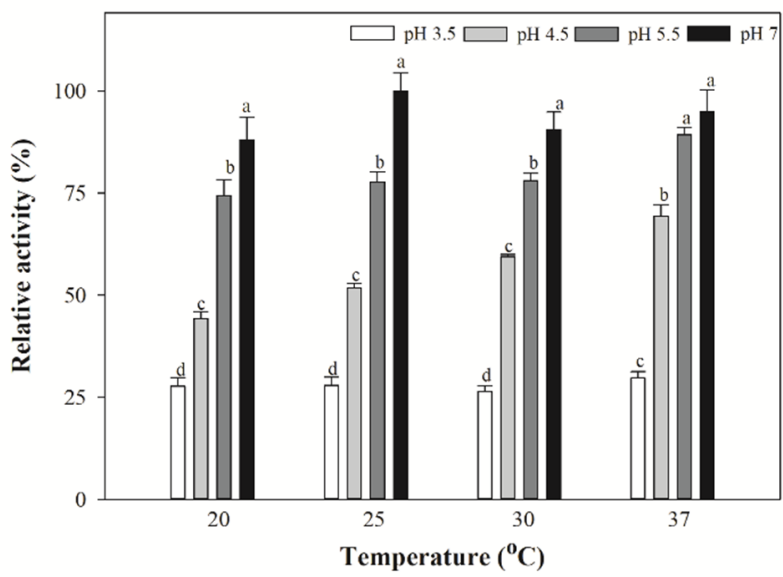

(c)

Figure 4. The $\beta$-lyase activity of (a) E. limosum, (b) Lb. casei, and (c) S. putrefaciens bacterial extracts at various temperatures and $\mathrm{pH}$. The $\mathrm{C}$-S $\beta$-lyase specific activities were determined by the DTNB assay using $1 \mathrm{mM}_{\mathrm{L}}$-cystathionine at 20,2530 , and $37^{\circ} \mathrm{C}$, and at $\mathrm{pH}$ values of $3.5,4.5,5.5$, and 7.0. Relative activity of $100 \%$ represented the highest value among all the specific activity in different temperatures and $\mathrm{pH}$. Data are expressed as mean \pm standard deviation $(n=3)$. Different lower case letters in the same grouped bars indicate significant differences $(p<0.05)$.

Some studies have indicated that various enzymes with carbon-sulfur lyase activities could have different optimum $\mathrm{pH}$ values. Allegrin et al. [11] found that both $\mathrm{k}_{\text {cat }}$ and specificity constant of the homotetrameric carbon-sulfur lyase from Lactobacillus delbrueckii subsp. bulgaricus were relatively better at $\mathrm{pH} 8$ or higher and decreased with the decreasing $\mathrm{pH}$, which indicated that the deprotonation of the enzyme's functional groups is essential 
for its catalysis activity. Intriguingly, Irmler et al. [22] assayed the $\beta$-lyase activity of several $L$. casei strain cell lysates at different $\mathrm{pH}$ values, and the results showed that all cell lysates had no $\beta$-lyase activity at basic $\mathrm{pH}$. Additionally, some of the L. casei strain cell lysates showed no differences for $\beta$-lyase activity at various $\mathrm{pH}$ values, whereas the others showed better $\beta$-lyase activity at acidic $\mathrm{pH}$. These results may indicate that there are multiple enzymes with $\beta$-lyase activity in the tested lactic acid bacteria. Although the optimum temperature and $\mathrm{pH}$ for each $\beta$-lyase from various microbial strains can be different, the cell extracts from all strains exhibited $\beta$-lyase activities in all tested $\mathrm{pH}$ and temperatures (Figures 3 and 4). In addition, our $\beta$-lyase activity data (Tables 1 and 2 ) indicated that the S. putrefaciens extracts exhibited higher $\beta$-lyase activity $(\mathrm{U} / \mathrm{mL})$ at neutral $\mathrm{pH}$ than any other strains by 4.4-21.9-, 6.4-29.8-, and 2.9-14.9-fold against L-cystathionine, L-cystine, and L-methionine, respectively. These results suggested that the $S$. putrefaciens extracts had the best potential to produce sulfur-containing aroma compounds at a suitable catalysis environment, such as neutral $\mathrm{pH}$. However, the $\beta$-lyase activity of the $S$. putrefaciens extracts was reduced by 70.3-73.6\% at $\mathrm{pH}$ 3.5. Thus, in an acidic environment such as wine-making ( $\mathrm{pH} 3.0-3.5$ ), the GRAS (generally recognized as safe) yeast $S$. cerevisiae 21584 and $K$. lactis extracts might be suitable candidates for the enrichment of sulfurcontaining aroma compounds. Both of them showed suitable $\beta$-lyase activity at acidic $\mathrm{pH}$, and the $\beta$-lyase activity of yeast $S$. cerevisiae 21584 at the tested temperatures showed no significant differences.

\subsection{Conversion of cys-4MMP into Aroma Compounds by Yeasts and Bacteria Extracts}

The difficulties in analyzing thiol aroma compounds produced by cell extracts include low product concentration, poor stability, and easy oxidation. Therefore, we used $4,4^{\prime}-$ dithiodipyridine (DTDP) to convert 4MMP into a stable derivatized 4MMP-DTDP [32] and then quantified it by LC-MS analysis to determine the product concentration of $4 \mathrm{MMP}$. As shown in Figure 5, 4MMP-DTDP showed an intense peak at $m / z 242.04$ in the mass spectrum, and a significant fragment signal at $m / z 144.0$ was observed in the subsequent MS/MS spectrum. Through MS analysis, we confirmed the completeness of the derivatization between DTDP and 4MMP reported by Capone et al. [23] and demonstrated that a characteristic product ion signal was suitable for quantification. The 4MMP-DTDP standard curve determined by monitoring the product ion signal showed a suitable correlation in the range of 1 and $50 \mathrm{ppm}$, with $\mathrm{R}^{2}>0.99$ (Figure $\mathrm{S1}$ ).

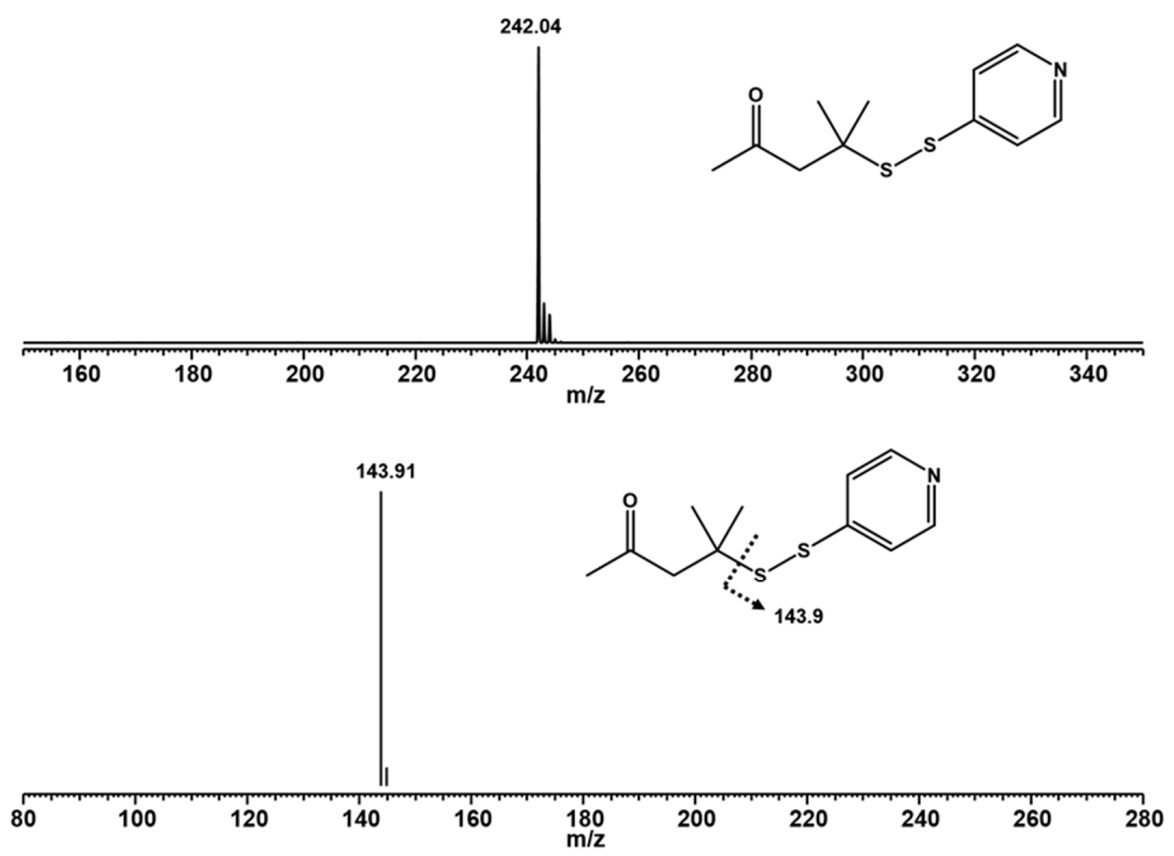

Figure 5. The full mass spectrum of 4MMP-DTDP (upper) and MS/MS spectrum of 4MMP-DTDP (lower). 
The concentration of $4 \mathrm{MMP}$ converted from cys-4MMP by mixing with different cell extracts possessing carbon-sulfur $\beta$-lyase from yeasts, such as K. lactis, S. cerevisiae, and Schizo. pombe, and bacteria, such as E. limosum, Lb. casei, and S. putrefaciens, is shown in Figure 6. S. cerevisiae 21584 exhibited the highest conversion efficiency to $4 \mathrm{MMP}$ in yeasts, and $S$. putrefaciens showed the highest conversion rate in all bacterial strains and all six test cell extracts. We believe that this is the first study to compare the ability of yeast and bacterial extracts in converting the $4 \mathrm{MMP}$ precursor into the aroma compound 4MMP.

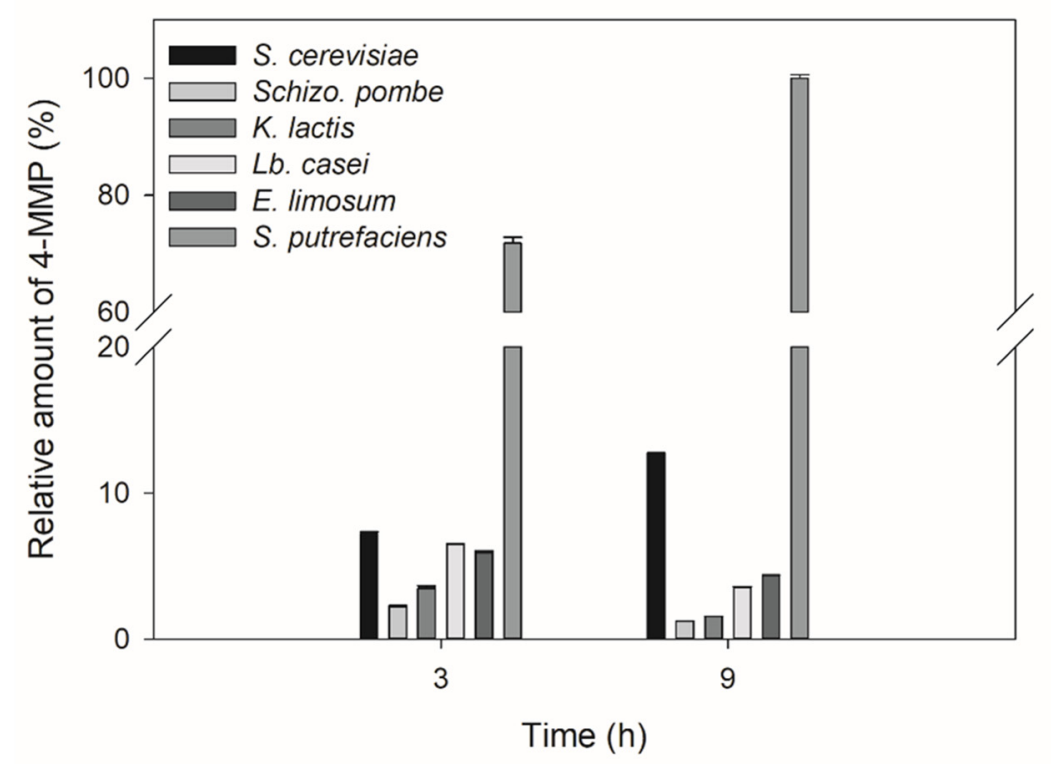

Figure 6. The relative production of $4 \mathrm{MMP}$ from Cys-4MMP by microbial cell extracts.

Cell extracts, crudes enzymes, and purified enzymes have been reported to be used in aroma modification and production. Klein et al. [33] used the cell extract of Lact. helveticus to convert free amino acids to produce neutral volatile aroma compounds benzaldehyde, dimethyl disulfide, and 2-methyl propanol to enhance and/or diversify the flavor of dairy products. Ricci et al. [7] added the cell extract of $L b$. casei into elderberry juice to increase the ester, phenol, and terpene contents in the juice, enhancing the aroma of elderberry. Commercially available aroma-enhancing enzymes Rapidase AR 2000 has been used in the hydrolysis of aroma glycosides for aroma enrichment during wine-making. To our knowledge, the research for microbial $\beta$-lyase activity and its application for aroma compound production remains limited. This study systematically screened bacteria and yeasts for their cysteine-S-conjugate $\beta$-lyase activities and investigated their optimum $\mathrm{pH}$ and temperatures. Our data show that the crude extract of $S$. putrefaciens exhibited high $\beta$-lyase activity and its ability to release 4MMP from its precursor cys-4MMP. Indeed, cell extracts and crude enzymes are advantageous for lower costs and fewer purification steps with reasonable biological activities [34], whereas purified enzymes have the benefits of rapid and stable chemical catalysis. We believe that this study can be used as a reference for the practical application of $\beta$-lyase in aroma modification and production.

\section{Conclusions}

Owing to the increasing demands for natural flavors, aroma compounds' production via microbial fermentation and enzymatic transformation has been drawing attention recently. $4 \mathrm{MMP}$, an aroma compound with the box tree and black currant flavors in wine, has been reported to be released by cysteine-S-conjugate $\beta$-lyases from its precursors. This study systematically screened bacteria and yeasts for their cysteine-S-conjugate $\beta$ lyase activities and investigated their optimum $\mathrm{pH}$ and temperatures. We also showed that the microbial extracts could be used to release $4 \mathrm{MMP}$ from its precursor cys-4MMP. Furthermore, we provided a relatively eco-friendly and economical method for large- 
scale preparation of precursor cys-4MMP with a higher yield. These findings provide more possibilities to produce more efficiently the 4MMP or other sulfur-containing aroma compounds. Our ultimate goal is to develop a sustainable process platform for sulfurcontaining aroma compounds that fulfill the synthesis criteria to produce the "natural" flavoring substances.

Supplementary Materials: The following are available online at https: / www.mdpi.com/article / 10.3390/fermentation7030129/s1, Figure S1: Standard calibration curves of 4MMP-DTDP in the concentration range of $1 \mathrm{ppm}$ to $50 \mathrm{ppm}$ were based on the extracted ion chromatogram of (A) precursor ion signal of 4MMP-DTDP at $\mathrm{m} / \mathrm{z} 242.0$, and (B) product ion signal of 4MMP-DTDP at $\mathrm{m} / \mathrm{z}$ 144.0, Table S1: Comparison of different purification methods for cys-4MMP production.

Author Contributions: H.-T.V.L., T.-C.L. and P.-H.H. conceived and designed the experiments; H.K.L., C.-F.C., H.-J.L., J.-L.L., Y.-T.L., Y.-H.W. and C.-Y.L. performed the experiments; H.-K.L., C.-F.C., H.-J.L. and C.-Y.L. analyzed the data; H.-K.L., H.-J.L., C.-Y.L., H.-T.V.L., T.-C.L. and P.-H.H. wrote the paper. All authors have read and agreed to the published version of the manuscript.

Funding: This research was funded by the Ministry of Science and Technology in Taiwan (MOST 1082221-E-019-041-MY2) and by the Center of Excellence for the Oceans, National Taiwan Ocean University from The Featured Areas Research Center Program within the framework of the Higher Education Sprout Project by the Ministry of Education (MOE) in Taiwan (NTOU-RD-AA-2021-1-02018).

Acknowledgments: We thank Academia Sinica High-Field NMR Center (HFNMRC) for technical support; HFNMRC is funded by Academia Sinica Core Facility and Innovative Instrument Project (AS-CFII-108-112).

Conflicts of Interest: The authors declare no conflict of interest.Abbreviations: 4MMP (4-Mercapto4-methyl-2-pentanone); cys-4MMP (cysteine-conjugate of 4MMP); 4MMP-DTDP (4MMP-4,4-Dithio dipyridine); TLC (thin-layer chromatography); NMR (nuclear magnetic resonance); GC-MS (gas chromatography-mass spectrometry); HSQC (heteronuclear single quantum coherence); LTQ (linear trap quadrupole); GRAS (generally recognized as safe).

\section{References}

1. MarketsandMarkets. Food Flavors Market by Type (Chocolate \& Browns, Vanilla, Fruit \& Nut, Dairy, Spices), Application (Beverages, Dairy, Confectionery, Bakery, Meat, Savory \& Snacks), Origin (Natural, Nature identical, Artificial), Form, and Region-Global Forecast to 2025. Available online: https://www.marketsandmarkets.com/Market-Reports/food-flavorsmarket-93115891.html?gclid=CjwKCAjwgOGCBhAlEiwA7FUXkqVLaoy5qRdNMauvJdfTe-Lco2tDgZYDUNCq3c7UtmMcus6 LdZYbuhoCw40QAvD_BwE (accessed on 23 March 2021).

2. Kutyna, D.R.; Borneman, A.R. Heterologous production of flavour and aroma compounds in Saccharomyces cerevisiae. Genes 2018, 9, 326. [CrossRef]

3. Schwab, W.; Davidovich-Rikanati, R.; Lewinsohn, E. Biosynthesis of plant-derived flavor compounds. Plant J. 2008, 54, 712-732. [CrossRef]

4. Gomez-Torres, N.; Garde, S.; Peiroten, A.; Avila, M. Impact of Clostridium spp. on cheese characteristics: Microbiology, color, formation of volatile compounds and off-flavors. Food Control 2015, 56, 186-194. [CrossRef]

5. Gallage, N.J.; Moller, B.L. Vanillin-bioconversion and bioengineering of the most popular plant flavor and its de novo biosynthesis in the vanilla orchid. Mol. Plant 2015, 8, 40-57. [CrossRef] [PubMed]

6. Muheim, A.; Mueller, B.; Muench, T.; Wetli, M.G.R.I. Process for the Production of Vanillin. European Patent Office, EP0885968 (A1), 23 December 1998.

7. Ricci, A.; Levante, A.; Cirlini, M.; Calani, L.; Bernini, V.; Del Rio, D.; Galaverna, G.; Neviani, E.; Lazzi, C. The influence of viable cells and cell-free extracts of Lactobacillus casei on volatile compounds and polyphenolic profile of elderberry juice. Front. Microbiol. 2018, 9, 2784. [CrossRef]

8. Tominaga, T.; des Gachons, C.P.; Dubourdieu, D. A new type of flavor precursors in Vitis vinifera L cv Sauvignon blanc: S-cysteine conjugates. J. Agric. Food Chem. 1998, 46, 5215-5219. [CrossRef]

9. Dhake, K.P.; Tambade, P.J.; Qureshi, Z.S.; Singhal, R.S.; Bhanage, B.M. HPMC-PVA film immobilized Rhizopus oryzae lipase as a biocatalyst for transesterification reaction. Acs Catal. 2011, 1, 316-322. [CrossRef]

10. Maicas, S.; Mateo, J.J. Microbial glyucosidases for wine production. Beverages 2016, 2, 20. [CrossRef]

11. Allegrini, A.; Astegno, A.; La Verde, V.; Dominici, P. Characterization of C-S lyase from Lactobacillus delbrueckii subsp. bulgaricus ATCC BAA-365 and its potential role in food flavour applications. J. Biochem. 2017, 161, 349-360. [CrossRef]

12. Parker, J.K. Flavour Development, Analysis and Perception in Food and Beverages; Woodhead Pub.: Waltham, MA, USA, $2014 ;$ p. 423. 
13. Cooper, A.J.; Krasnikov, B.F.; Niatsetskaya, Z.V.; Pinto, J.T.; Callery, P.S.; Villar, M.T.; Artigues, A.; Bruschi, S.A. Cysteine S-conjugate $\beta$-lyases: Important roles in the metabolism of naturally occurring sulfur and selenium-containing compounds, xenobiotics and anticancer agents. Amino Acids 2011, 41, 7-27. [CrossRef]

14. Lee, W.J.; Banavara, D.S.; Hughes, J.E.; Christiansen, J.K.; Steele, J.L.; Broadbent, J.R.; Rankin, S.A. Role of cystathionine beta-lyase in catabolism of amino acids to sulfur volatiles by genetic variants of Lactobacillus helveticus CNRZ 32. Appl. Environ. Microbiol. 2007, 73, 3034-3039. [CrossRef] [PubMed]

15. Zha, M.; Yin, S.; Sun, B.; Wang, X.; Wang, C. STR3 and CYS3 contribute to 2-furfurylthiol biosynthesis in Chinese sesame-flavored Baijiu yeast. J. Agric. Food Chem. 2017, 65, 5503-5511. [CrossRef] [PubMed]

16. Zha, M.; Sun, B.; Yin, S.; Mehmood, A.; Cheng, L.; Wang, C. Generation of 2-furfurylthiol by carbon-sulfur lyase from the Baijiu Yeast Saccharomyces cerevisiae G20. J. Agric. Food Chem. 2018, 66, 2114-2120. [CrossRef] [PubMed]

17. Darriet, P.; Lavigne, V.; Boidron, J.D.D. Identification of a powerful aromatic component of Vitis vinifera L. var. sauvignon wines: 4-mercapto-4-methylpentan-2-one. Flavour Frag J. 1995, 10, 385-392. [CrossRef]

18. Tominaga, T.; Furrer, A.; Henry, R.; Dubourdieu, D. Identification of new volatile thiols in the aroma of Vitis vinifera L. var. Sauvignon blanc wines. Flavour Frag. J 1998, 13, 159-162. [CrossRef]

19. Howell, K.S.; Swiegers, J.H.; Elsey, G.M.; Siebert, T.E.; Bartowsky, E.J.; Fleet, G.H.; Pretorius, I.S.; Pretorius, S.; Lopes, M.A.D. Variation in 4-mercapto-4-methyl-pentan-2-one release by Saccharomyces cerevisiae commercial wine strains. FEMS Microbiol. Lett. 2004, 240, 125-129. [CrossRef]

20. Murat, M.L.; Masneuf, I.; Darriet, P.; Lavigne, V.; Tominaga, T.; Dubourdieu, D. Effect of Saccharomyces cerevisiae yeast strains on the liberation of volatile thiols in Sauvignon blanc wine. Am. J. Enol. Vitic. 2001, 52, 136-139.

21. Yoshida, Y.; Negishi, M.; Amano, A.; Oho, T.; Nakano, Y. Differences in the betaC-S lyase activities of viridans group streptococci. Biochem. Biophys. Res. Commun. 2003, 300, 55-60. [CrossRef]

22. Irmler, S.; Raboud, S.; Beisert, B.; Rauhut, D.; Berthoud, H. Cloning and characterization of two Lactobacillus casei genes encoding a cystathionine lyase. Appl. Environ. Microbiol. 2008, 74, 99-106. [CrossRef]

23. Capone, D.L.; Ristic, R.; Pardon, K.H.; Jeffery, D.W. Simple quantitative determination of potent thiols at ultratrace levels in wine by derivatization and high-performance liquid chromatography-tandem mass spectrometry (HPLC-MS/MS) analysis. Anal. Chem. 2015, 87, 1226-1231. [CrossRef]

24. Starkenmann, C. Analysis of a model reaction system containing cysteine and (E)-2-methyl-2-butenal, (E)-2-hexenal, or mesityl oxide. J. Agric. Food Chem. 2003, 51, 7146-7155. [CrossRef]

25. Hebditch, K.R.; Nicolau, L.; Brimble, M.A. Synthesis of isotopically labelled thiol volatiles and cysteine conjugates for quantification of Sauvignon Blanc wine. J. Labelled Compd. Radiopharm. 2007, 50, 237-243. [CrossRef]

26. Holt, S.; Cordente, A.G.; Curtin, C. Saccharomyces cerevisiae STR3 and yeast cystathionine $\beta$-lyase enzymes: The potential for engineering increased flavor release. Bioengineered 2012, 3, 178-180. [CrossRef] [PubMed]

27. Holt, S.; Cordente, A.G.; Williams, S.J.; Capone, D.L.; Jitjaroen, W.; Menz, I.R.; Curtin, C.; Anderson, P.A. Engineering Saccharomyces cerevisiae to release 3-Mercaptohexan-1-ol during fermentation through overexpression of an S. cerevisiae Gene, STR3, for improvement of wine aroma. Appl. Environ. Microbiol. 2011, 77, 3626-3632. [CrossRef]

28. Alting, A.C.; Engels, W.J.M.; Vanschalkwijk, S.; Exterkate, F.A. Purification and characterization of cystathionine beta-lyase from Lactococcus lactis subsp, cremoris B78 and its possible role in flavor development in cheese. Appl. Environ. Microbiol. 1995, 61, 4037-4042. [CrossRef]

29. Bruinenberg, P.G.; deRoo, G.; Limsowtin, G.K.Y. Purification and characterization of cystathionine gamma-lyase from Lactococcus lactis subsp cremoris SK11: Possible role in flavor compound formation during cheese maturation. Appl. Environ. Microbiol. 1997, 63, 561-566. [CrossRef]

30. Wu, G.; Li, N.; Mao, Y.; Zhou, G.; Gao, H. Endogenous generation of hydrogen sulfide and its regulation in Shewanella oneidensis. Front. Microbiol. 2015, 6, 374. [CrossRef] [PubMed]

31. Fernandez, M.; Kleerebezem, M.; Kuipers, O.P.; Siezen, R.J.; van Kranenburg, R. Regulation of the metC-cysK operon, involved in sulfur metabolism in Lactococcus lactis. J. Bacteriol. 2002, 184, 82-90. [CrossRef]

32. Fedrizzi, B.; Pardon, K.H.; Sefton, M.A.; Elsey, G.M.; Jeffery, D.W. First identification of 4-S-glutathionyl-4-methylpentan2-one, a potential precursor of 4-mercapto-4-methylpentan-2-one, in Sauvignon blanc juice. J. Agric. Food Chem. 2009, 57, 991-995. [CrossRef]

33. Klein, N.; Maillard, M.B.; Thierry, A.; Lortal, S. Conversion of amino acids into aroma compounds by cell-free extracts of Lactobacillus helveticus. J. Appl. Microbiol. 2001, 91, 404-411. [CrossRef]

34. Cardoso, W.S.; Queiroz, P.V.; Tavares, G.P.; Santos, F.A.; Soares, F.E.F.; Kasuya, M.C.M.; Queiroz, J.H. Multi-enzyme complex of white rot fungi in saccharification of lignocellulosic material. Braz. J. Microbiol. 2018, 49, 879-884. [CrossRef] 